\title{
EFFECT OF THE APPLICATION OF SEWAGE SLUDGE COMPOST ON THE CONTENT AND LEACHING OF ZINC AND COPPER FROM SOILS UNDER AGRICULTURAL USE
}

\author{
Teresa Bowszys' ${ }^{1}$ Jadwiga Wierzbowska', Paweł Sternik' ${ }^{1}$, Marta Karolina Busse' \\ 1 Department of Agricultural Chemistry and Environmental Protection, University of Warmia and Mazury in \\ Olsztyn, Oczapowskiego 8, 10-744 Olsztyn, Poland, e-mail: teresa.bowszys@uwm.edu.pl
}

Received: 2014.08.28

Accepted: 2014.10.17

Published: 2015.01.02

\begin{abstract}
Municipal sewage sludge can be used in agriculture provided that the permissible levels of heavy metals are not exceeded in either the sewage sludge or in the top layer of soil to be amended by this substance, and that its application does not deteriorate the soil quality. The purpose of this study was to determine the effects of different forms of sewage sludge on the content of $\mathrm{Cu}$ and $\mathrm{Zn}$ in soil and in soil leachate. The study comprised 2 rotations (potato, spring barley, winter oilseed rape, winter wheat). Each series was composed of the following treatments: NPK, FYM, municipal sewage sludge composted with straw, dried and granulated municipal sewage. FYM and composted sewage were applied once in the rotation (under potato) in a dose of 10 $\mathrm{Mg}$ d.m. ha ${ }^{-1}$ and twice (under potato and under winter oilseed rape) in a dose of 5 $\mathrm{Mg}$ d.m. ha ${ }^{-1}$. In the other years (under spring barley and winter wheat), soil received only mineral fertilization. In order to evaluate the effect of the composts on the leaching of $\mathrm{Cu}$ and $\mathrm{Zn}$ from soil, a lysimetric experiment was conducted under controlled conditions. Before the experiment, the soil content of $\mathrm{Cu}$ was low $\left(1.47 \mathrm{mg} \mathrm{kg}^{-1}\right)$ and $\mathrm{Zn}$ was medium $\left(10.11 \mathrm{mg} \mathrm{kg}^{-1}\right)$. The content of copper in the composts ranged from 4.5 to $340.1 \mathrm{mg} \mathrm{kg}^{-1} \mathrm{~d} . \mathrm{m}$. and that of zinc was from 109.5 to $1310.1 \mathrm{mg} \mathrm{kg}^{-1} \mathrm{~d} . \mathrm{m}$. The composted sewage sludge significantly raised the soil content of available forms of $\mathrm{Cu}$ and $\mathrm{Zn}$, but did not change the soil nutrient abundance class. Fertilization modified the content of the microelements in the soil leachate.
\end{abstract}

Keywords: sewage sludge, composts, zinc, copper, soil leachate.

\section{INTRODUCTION}

With the continually growing amounts of municipal sewage sludge, the problem of its recycling becomes more and more important. Sewage sludge is a noxious but unavoidable by-product of sewage and wastewater treatment. According to the Main Statistial Office (GUS), the total amount of sewage sludge generated in Poland in 2012 was 533.3 thousand tons of d.m., of which 115 thousand tons were then used in agriculture [GUS 2013]. Apart from farming, sewage sludge can also be used to rehabilitate degraded land (50.3 thousand tons of dry matter) and to cultivate plants grown for compost (33.3 thousand tons of d.m.). One of the most rational ways to utilize this waste is their use in composted forms for agricultural purposes. Raw and composted sewage sludge is a valuable source of organic matter and nutrients, hence its use as an unconventional soil amending substance [Sądej et al. 2007, Bowszys et al. 2009a]. However, such products must satisfy a number of safety standards to avoid environmental pollution. As the civilization advances, the amount of waste increases and its chemical composition changes. Depending on its place of origin, waste may contain large amounts of harmful substances, mainly heavy metals, PAHs, PCBs, microbial and parasitic contaminants [Iżewska 2007, Milinovic et al. 2014]. To gain deep and thorough knowledge of the ecological consequences of the incoproration of composted 
waste to soil, it is necessary to complete a broad range of basic and experimental studies, which will enable us to work out guidelines for rational and safe application of composts.

The purpose of this study was to determine the influence of different forms of sewage sludge on the content of $\mathrm{Cu}$ and $\mathrm{Zn}$ in soil and in soil leachate.

\section{MATERIAL AND METHODS}

The experiments comprised 2 rotation cycles: potato, spring barley, winter oilseed rape, winter wheat, run in the years 2004-2007 and 2008-2011. The following treatments were tested: NPK; FYM10, $2 \times 5$ Mg d.m.'ha ${ }^{-1}$; municipal sewage sludge composted with straw $10,2 \times 5 \mathrm{Mg}$ d.m. ha $^{-1}$; sewage sludge composted alone $10,2 \times 5$ Mg d.m. ha ${ }^{-1}$; dried and granulated sewage sludge 10, $2 \times 5 \mathrm{Mg}$ d.m. ha ${ }^{-1}$. FYM and sewage sludge composts used in a dose of $10 \mathrm{Mg}$ d.m. ha ${ }^{-1}$ were applied once in a rotation cycle, under potato (in 2004 and 2008), while the doses of $5 \mathrm{Mg} \mathrm{d} \cdot \mathrm{m} \cdot \mathrm{ha}^{-1}$ were given twice, under potato $(2004,2008)$ and under winter oilseed rape $(2006,2010)$. In other years, the crops were nourished only with mineral fertilizers: spring barley in 2005 and 2009, and winter wheat in 2007 and 2011. On the plots with FYM and organic substances, nitrogen was balanced depending on the $\mathrm{N}$-total content in the soil. The effect of composts on the potential volume of leached $\mathrm{Cu}$ and $\mathrm{Zn}$ was assessed in a model lysimetric experiment, carried out under controlled conditions. Soil samples from each rotation were collected after wheat harvest, from three layers of the soil horizon: 0-30 cm, 31-60 $\mathrm{cm}$ and $61-90 \mathrm{~cm}$. The total amount of water used for leaching corresponded to the average annual amount of atmospheric precipitation in the Province of Warmia and Mazury (605 mm).

The experiment was set up on proper brown podzolic soil developed from light boulder clay, which belonged to good wheat complex (2A gp. gc:gl) [Systematyka ... 2011]. Before the experiment, the soil was low in available (in $1 \mathrm{~mol}$ $\left.\mathrm{HCl} \cdot \mathrm{dm}^{-3}\right)$ forms of copper $\left(1.47 \mathrm{mg} \cdot \mathrm{kg}^{-1}\right)$ and moderately high in zinc $\left(10.11 \mathrm{mg} \cdot \mathrm{kg}^{-1}\right)$. The content of $\mathrm{Cu}$ in composts ranged from 4.5 to 340.1 $\mathrm{mg} \cdot \mathrm{kg}^{-1}$ d.m., Zn from 109.5 to $1310.1 \mathrm{mg} \cdot \mathrm{kg}^{-1}$ d.m., and its $\mathrm{pH}$ was 5.04 to $1 \mathrm{~mol} \mathrm{KCl} \cdot \mathrm{dm}^{-3}$.

Methods of chemical analyses: $\mathrm{Zn}$ and $\mathrm{Cu}$ in soil after extraction in $1 \mathrm{~mol} \mathrm{HCl} \cdot \mathrm{dm}^{-3}$ and in leachate were determined with the atomic absorbance spectrophotometric (AAS) method.

The results of chemical analyses were processed statistically with a software package Statistica $10^{\circ}$. The significance of differences between the data was verified by the Tukey's HSD (Honestly Signifficant Differences) test at the level of significance $\alpha=0.05$.

\section{RESULTS AND DISCUSSION}

The content of zinc in soil in the subsequent years of the research was similar and ranged on average from 6.41 to $15.14 \mathrm{mg} \cdot \mathrm{kg}^{-1}$ (Tables 1,2 ).

In both rotations, the highest concentration of zinc in soil was found after the harvest of winter oilseed rape $\left(15.14 \mathrm{mg} \cdot \mathrm{kg}^{-1}\right.$ and $\left.13.59 \mathrm{mg} \cdot \mathrm{kg}^{-1}\right)$, which had been treated with $5 \mathrm{Mg}$ d.m. ha ${ }^{-1}$ of FYM and composts. In the first rotation, soil fertilized with dried and granulated sewage sludge was significantly the most abundant of Zn among all the treatments where organic materials had been applied. It was also found out that after each four years of the research, compared to the NPK and FYM fertilization regimes, significatly more Zn was found in soil fertilized with composted sewage sludge (with and without straw) and with dried and graulated sewage sludge. In turn, the frequency of soil application of the examined materials, i.e. once or twice in a rotation cycle, did not have any significant effect on the zinc content.

In the first rotation, the content of copper in soil was differentiated by the year and type of applied fertilizers and composts, ranging from 1.30 to $2.94 \mathrm{mg} \cdot \mathrm{kg}^{-1}$ (Table 3).

In the second rotation cycle, however, there were much fewer significant dependences between the experimental factors, and the cotent of copper ranged from 1.38 to $2.76 \mathrm{mg} \cdot \mathrm{kg}^{-1}$ (Table $4)$. In the first year of the experiment, the average content of copper in soil was $1.51 \mathrm{mg} \mathrm{Cu} \cdot \mathrm{kg}^{-1}$, increasing significantly up to $1.98 \mathrm{mg} \cdot \mathrm{kg}^{-1}$ in the fourth year of the cycle. In 2008 (1st year of the second cycle), the soil already contained an average of $1.65 \mathrm{mg} \mathrm{Cu} \cdot \mathrm{kg}^{-1}$, and a significant increase relative to this value was not achieved until four years afterwards $\left(2.27 \mathrm{mg} \cdot \mathrm{kg}^{-1}\right)$. After the first four years of the research, significantly more $\mathrm{Cu}$ - relative to its content in soil fertilized with FYM - was found in soil enriched with sewage sludge composts (with straw $+4 \%$ and without straw $+16 \%$ ) and with dried and granulated 
Table 1. Content of available forms of zinc in soil in the first rotation cycle $\left(\mathrm{mg} \mathrm{Zn} \cdot \mathrm{kg}^{-1}\right)$

\begin{tabular}{|c|c|c|c|c|c|c|c|}
\hline Year & $\begin{array}{l}\text { Frequency of } \\
\text { application }\end{array}$ & NPK & FYM & $\begin{array}{l}\text { Compost from } \\
\text { sewage sludge } \\
\text { and straw }\end{array}$ & $\begin{array}{l}\text { Compost from } \\
\text { sewage sludge }\end{array}$ & $\begin{array}{c}\text { Dried and } \\
\text { granulated } \\
\text { sewage sludge }\end{array}$ & Mean \\
\hline \multirow{3}{*}{2004} & $a$ & \multirow{3}{*}{11.21} & 8.53 & 10.07 & 12.52 & 15.84 & 11.63 \\
\hline & $\mathrm{b}$ & & 9.40 & 10.48 & 10.50 & 11.60 & 10.64 \\
\hline & mean & & 8.97 & 10.28 & 11.51 & 13.72 & 11.14 \\
\hline \multirow{3}{*}{2005} & $a$ & \multirow{3}{*}{4.76} & 5.56 & 7.03 & 8.13 & 7.88 & 6.67 \\
\hline & $\mathrm{b}$ & & 5.77 & 6.45 & 6.81 & 6.98 & 6.16 \\
\hline & mean & & 5.67 & 6.74 & 7.47 & 7.43 & 6.41 \\
\hline \multirow{3}{*}{2006} & $a$ & \multirow{3}{*}{9.01} & 11.06 & 19.41 & 11.16 & 20.49 & 14.23 \\
\hline & $\mathrm{b}$ & & 11.50 & 14.18 & 18.56 & 27.04 & 16.06 \\
\hline & mean & & 11.28 & 16.80 & 14.86 & 23.77 & 15.14 \\
\hline \multirow{3}{*}{2007} & $a$ & \multirow{3}{*}{5.55} & 8.90 & 7.70 & 9.53 & 15.06 & 9.35 \\
\hline & $\mathrm{b}$ & & 6.51 & 8.38 & 9.66 & 24.66 & 10.95 \\
\hline & mean & & 7.71 & 8.04 & 9.59 & 19.86 & 10.15 \\
\hline \multirow{3}{*}{ Mean } & $a$ & \multirow{3}{*}{7.63} & 8.51 & 11.05 & 10.33 & 14.82 & 10.47 \\
\hline & $\mathrm{b}$ & & 8.30 & 9.88 & 11.38 & 17.57 & 10.95 \\
\hline & mean & & 8.41 & 10.46 & 10.86 & 16.19 & - \\
\hline \multicolumn{8}{|c|}{$\begin{array}{l}\text { HSD P }<0.05 \\
\text { year of experiment } 1.21 \\
\text { fertilizer } 1.49 \\
\text { frequency of application n.s. } \\
\text { year*fertilizer } 3.84 \\
\text { year* frequency of application } 1.72 \\
\text { fertilizer* frequency of application } 2.11 \\
\text { year*fertilizer* frequency of application } 5.43\end{array}$} \\
\hline
\end{tabular}

$\mathrm{a}$ - once in a rotation; $\mathrm{b}$ - twice in a rotation

Table 2. Content of available $\mathrm{Zn}$ forms in soil in the second rotation cycle $\left(\mathrm{mg} \mathrm{Zn} \cdot \mathrm{kg}^{-1}\right)$

\begin{tabular}{|c|c|c|c|c|c|c|c|}
\hline Year & $\begin{array}{l}\text { Frequency of } \\
\text { application }\end{array}$ & NPK & FYM & $\begin{array}{l}\text { Compost from } \\
\text { sewage sludge } \\
\text { and straw }\end{array}$ & $\begin{array}{l}\text { Compost from } \\
\text { sewage sludge }\end{array}$ & $\begin{array}{c}\text { Dried and } \\
\text { granulated } \\
\text { sewage sludge }\end{array}$ & Mean \\
\hline \multirow{3}{*}{2008} & $a$ & \multirow{3}{*}{9.76} & 12.10 & 12.83 & 11.96 & 17.30 & 12.79 \\
\hline & $\mathrm{b}$ & & 10.57 & 15.91 & 17.33 & 12.45 & 13.21 \\
\hline & mean & & 11.33 & 14.37 & 14.65 & 14.88 & 13.00 \\
\hline \multirow{3}{*}{2009} & $a$ & \multirow{3}{*}{7.02} & 8.79 & 11.62 & 9.73 & 11.52 & 9.74 \\
\hline & $\mathrm{b}$ & & 10.80 & 9.48 & 11.08 & 10.29 & 9.73 \\
\hline & mean & & 9.80 & 10.55 & 10.40 & 10.91 & 9.74 \\
\hline \multirow{3}{*}{2010} & $a$ & \multirow{3}{*}{12.60} & 10.36 & 13.03 & 14.69 & 18.72 & 13.88 \\
\hline & $\mathrm{b}$ & & 10.06 & 13.22 & 14.59 & 16.03 & 13.30 \\
\hline & mean & & 10.21 & 13.13 & 14.64 & 17.38 & 13.59 \\
\hline \multirow{3}{*}{2011} & $a$ & \multirow{3}{*}{12.62} & 8.40 & 13.10 & 13.09 & 14.27 & 12.30 \\
\hline & $\mathrm{b}$ & & 10.89 & 10.56 & 10.26 & 12.41 & 11.35 \\
\hline & mean & & 9.65 & 11.83 & 11.68 & 13.34 & 11.82 \\
\hline \multirow{3}{*}{ Mean } & $a$ & \multirow{3}{*}{10.50} & 9.91 & 12.65 & 12.37 & 15.46 & 12.18 \\
\hline & $\mathrm{b}$ & & 10.58 & 12.29 & 13.32 & 12.80 & 11.90 \\
\hline & mean & & 10.25 & 12.47 & 12.84 & 14.13 & - \\
\hline \multicolumn{8}{|c|}{$\begin{array}{l}\text { HSD P<0.05 } \\
\text { year of experiment } 1.52 \\
\text { fertilizer } 1.87 \\
\text { frequency of application n.s. } \\
\text { yearfertilizer } 4.80 \\
\text { year* frequency of application n.s. } \\
\text { fertilizer* frequency of application n.s. } \\
\text { year*fertilizer }{ }^{\star} \text { frequency of application n.s. }\end{array}$} \\
\hline
\end{tabular}

$\mathrm{a}$ - once in a rotation; $\mathrm{b}$ - twice in a rotation 
Table 3. Content of available $\mathrm{Cu}$ forms in soil in the first rotation cycle $\left(\mathrm{mg} \mathrm{Cu} \cdot \mathrm{kg}^{-1}\right)$

\begin{tabular}{|c|c|c|c|c|c|c|c|}
\hline Year & $\begin{array}{l}\text { Frequency of } \\
\text { application }\end{array}$ & NPK & FYM & $\begin{array}{c}\text { Compost from } \\
\text { sewage sludge } \\
\text { and straw }\end{array}$ & $\begin{array}{l}\text { Compost from } \\
\text { sewage sludge }\end{array}$ & $\begin{array}{c}\text { Dried and } \\
\text { granulated } \\
\text { sewage sludge }\end{array}$ & Mean \\
\hline \multirow{3}{*}{2004} & $\mathrm{a}$ & \multirow{3}{*}{1.49} & 1.43 & 1.67 & 1.49 & 1.61 & 1.54 \\
\hline & $\mathrm{b}$ & & 1.17 & 1.15 & 1.67 & 1.97 & 1.49 \\
\hline & mean & & 1.30 & 1.41 & 1.58 & 1.79 & 1.51 \\
\hline \multirow{3}{*}{2005} & $a$ & \multirow{3}{*}{1.48} & 1.53 & 1.72 & 1.79 & 1.83 & 1.67 \\
\hline & $\mathrm{b}$ & & 1.52 & 1.46 & 1.70 & 1.75 & 1.58 \\
\hline & mean & & 1.53 & 1.59 & 1.74 & 1.79 & 1.63 \\
\hline \multirow{3}{*}{2006} & $a$ & \multirow{3}{*}{1.33} & 1.56 & 1.63 & 1.74 & 1.95 & 1.64 \\
\hline & $\mathrm{b}$ & & 1.55 & 1.58 & 1.83 & 1.92 & 1.64 \\
\hline & mean & & 1.55 & 1.60 & 1.79 & 1.93 & 1.64 \\
\hline \multirow{3}{*}{2007} & $a$ & \multirow{3}{*}{1.53} & 1.87 & 1.77 & 1.87 & 2.21 & 1.85 \\
\hline & $\mathrm{b}$ & & 1.61 & 1.72 & 2.06 & 3.67 & 2.12 \\
\hline & mean & & 1.74 & 1.74 & 1.96 & 2.94 & 1.98 \\
\hline \multirow{3}{*}{ Mean } & $a$ & \multirow{3}{*}{1.46} & 1.60 & 1.70 & 1.72 & 1.90 & 1.67 \\
\hline & $\mathrm{b}$ & & 1.46 & 1.48 & 1.82 & 2.33 & 1.71 \\
\hline & mean & & 1.53 & 1.59 & 1.77 & 2.11 & - \\
\hline \multicolumn{8}{|c|}{$\begin{array}{l}\text { HSD P }<0.05 \\
\text { year of experiment } 0.11 \\
\text { fertilizer } 0.13 \\
\text { frequency of application n.s. } \\
\text { year*fertilizer } 0.34 \\
\text { year* frequency of application } 0.15 \\
\text { feartilizer* frequency of application } 0.18 \\
\text { year*fertilizer* frequency of application } 0.47\end{array}$} \\
\hline
\end{tabular}

$\mathrm{a}$ - once in a rotation; $\mathrm{b}$ - twice in a rotation

Table 4. Content of available $\mathrm{Cu}$ forms in soil in the second rotation cycle $\left(\mathrm{mg} \mathrm{Cu} \cdot \mathrm{kg}^{-1}\right)$

\begin{tabular}{|c|c|c|c|c|c|c|c|}
\hline Year & $\begin{array}{l}\text { Frequency of } \\
\text { application }\end{array}$ & NPK & FYM & $\begin{array}{l}\text { Compost from } \\
\text { sewage sludge } \\
\text { and straw }\end{array}$ & $\begin{array}{l}\text { Compost from } \\
\text { sewage sludge }\end{array}$ & $\begin{array}{c}\text { Dried and } \\
\text { granulated } \\
\text { sewage sludge }\end{array}$ & Mean \\
\hline \multirow{3}{*}{2008} & $a$ & \multirow{3}{*}{1.46} & 1.39 & 1.73 & 1.76 & 1.96 & 1.66 \\
\hline & $\mathrm{b}$ & & 1.37 & 1.57 & 1.91 & 1.93 & 1.65 \\
\hline & mean & & 1.38 & 1.65 & 1.83 & 1.94 & 1.65 \\
\hline \multirow{3}{*}{2009} & $a$ & \multirow{3}{*}{1.55} & 1.55 & 1.93 & 2.03 & 2.30 & 1.87 \\
\hline & $\mathrm{b}$ & & 1.45 & 1.73 & 2.21 & 2.16 & 1.82 \\
\hline & mean & & 1.50 & 1.83 & 2.12 & 2.23 & 1.85 \\
\hline \multirow{3}{*}{2010} & $a$ & \multirow{3}{*}{1.60} & 1.47 & 1.89 & 1.70 & 2.11 & 1.75 \\
\hline & b & & 1.28 & 1.50 & 1.36 & 3.42 & 1.83 \\
\hline & mean & & 1.37 & 1.70 & 1.53 & 2.76 & 1.79 \\
\hline \multirow{3}{*}{2011} & $a$ & \multirow{3}{*}{2.33} & 1.82 & 2.50 & 2.25 & 2.53 & 2.29 \\
\hline & $\mathrm{b}$ & & 2.33 & 2.21 & 2.05 & 2.38 & 2.26 \\
\hline & mean & & 2.08 & 2.36 & 2.15 & 2.45 & 2.27 \\
\hline \multirow{3}{*}{ Mean } & $a$ & \multirow{3}{*}{1.74} & 1.56 & 2.01 & 1.94 & 2.22 & 1.89 \\
\hline & $\mathrm{b}$ & & 1.61 & 1.75 & 1.88 & 2.47 & 1.89 \\
\hline & mean & & 1.58 & 1.88 & 1.91 & 2.35 & - \\
\hline \multicolumn{8}{|c|}{$\begin{array}{l}\text { HSD P }<0.05 \\
\text { year of experiment } 0.38 \\
\text { fertilizer } 0.47 \\
\text { frequency of application n.s. } \\
\text { yearfertilier n.s. } \\
\text { year* frequency of application n.s. } \\
\text { fertilizer* frequency of application n.s. } \\
\text { year*fertilizer }{ }^{\star} \text { frequency of application n.s. }\end{array}$} \\
\hline
\end{tabular}

$\mathrm{a}$ - once in a rotation; $\mathrm{b}$ - twice in a rotation 
sewage sludge $(+38 \%)$. In the second rotation cycle, a significat increase in the $\mathrm{Cu}$ content in soil $(+49 \%)$ was found only in response to dried compost. The frequency of application did not have any significant effect on the modification of the soil abundance of copper. In both rotations, a positive residual effect on this characteristic was demonstrated for the applied NPK fertilizers, FYM and composts.

During the treatment of wastewater and sewage, heavy metals are removed and accumulated in the sewage sludge. Their total content does not mirror the potential threat which they pose to the environment. Metals bound with aluminum silicates, metal sulphates and strong metal-organic bonds are immobile forms and do not create toxicological risk. Ion-exchangable forms, oxides and cabonates can permeate into soil and water environments, where they can be a source of nutrients for plants. However, in high concentrations, they can threaten plants as well as the soil and water environment [Gawdzik 2012]. Results of numerous investigations suggest some increase in the content of heavy metals observed in soils fertilized with sewage sludge, but it is small enough to leave the soil pollution class assignment as zero pollution soils [Bowszys et al. 2009b, Greinert et al. 2009, Niedźwiecki et al. 2009]. According to Sienkiewicz and Czarnecka [2012], in alkaline soils, a rise in the content of available forms of $\mathrm{Cu}, \mathrm{Zn}$ and $\mathrm{Mn}$ in a soil fertilized with large doses (up to $280 \mathrm{t}^{\cdot} \cdot \mathrm{ha}^{-1}$ ) did not threaten the environment, but just improved the nutrition of plants with these microelements. In another study, Sienkiewicz et al. [2009] showed that the content of available forms of copper, zinc and manganese in soil regularly fertilized with FYM was much higher than in soil with sole mineral fertilization. Gondek [2010] determined that fertilization with FYM and sewage sludge in the first year did not cause significant mobilization of mobile forms of zinc in soil. However, as a result of the mineralization of organic materials and progressing soil alkalization, in the second and third year of the experiment, the content of mobile zinc forms increased, although to a lesser extent than in response to mineral fertilization.

Trace minerals, if present in sewage sludge in high concentrations, can be a threat to the soil and water environment [Witczak, Adamczyk 1995, Rozporządzenie... 2008]. The volume of microelements lost by leaching is highly varied. The application of fertilizer components in doses highly exceeding the crops' nutritional demands may lead to changes in the ionic balance of the soil solution and cause the transfer of nutrients to groundwater [Gondek 2009]. A single application of even a large dose of sewage sludge will not trigger a distinct increase in leaching heavy metals from soil relative to FYM or mineral NPK fertilization. On the other hand, due to the positive balance of these elements in soil, long-term application of sewage sludge could be problematic, especially when soil acidity is raised and, consequently, the mobility of elements as well as their leachability are higher [Sevel et al. 2014]. Milinovic et al. [2014] claim that the drying of sewage sludge prior to its application to soil in general reduces the leaching of zinc but increases copper loss by leaching from the sludge. According to Page et al. [2014], the soil reaction cannot be treated as an exclusive indicator in the assessment of the mobility of heavy metals in soil, their phytoavailability and the risk of their migration

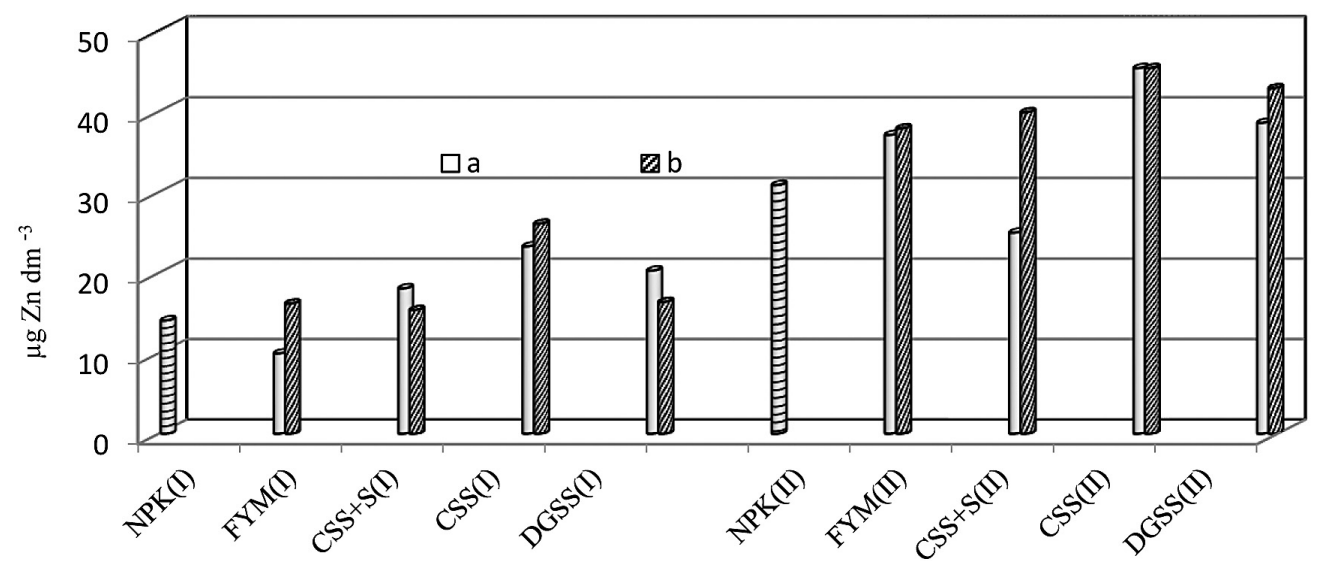

Figure 1. Content of zinc in leachate $(\mathrm{css}+\mathrm{s}$ - compost from sewage sludge and straw; css - compost from sewage sludge; dgss - dried and granulated sewage sludge; (I) - first rotation; (II) - second rotation; $\mathrm{a}-$ once in a rotation $\mathrm{b}$ - twice in a rotation) 


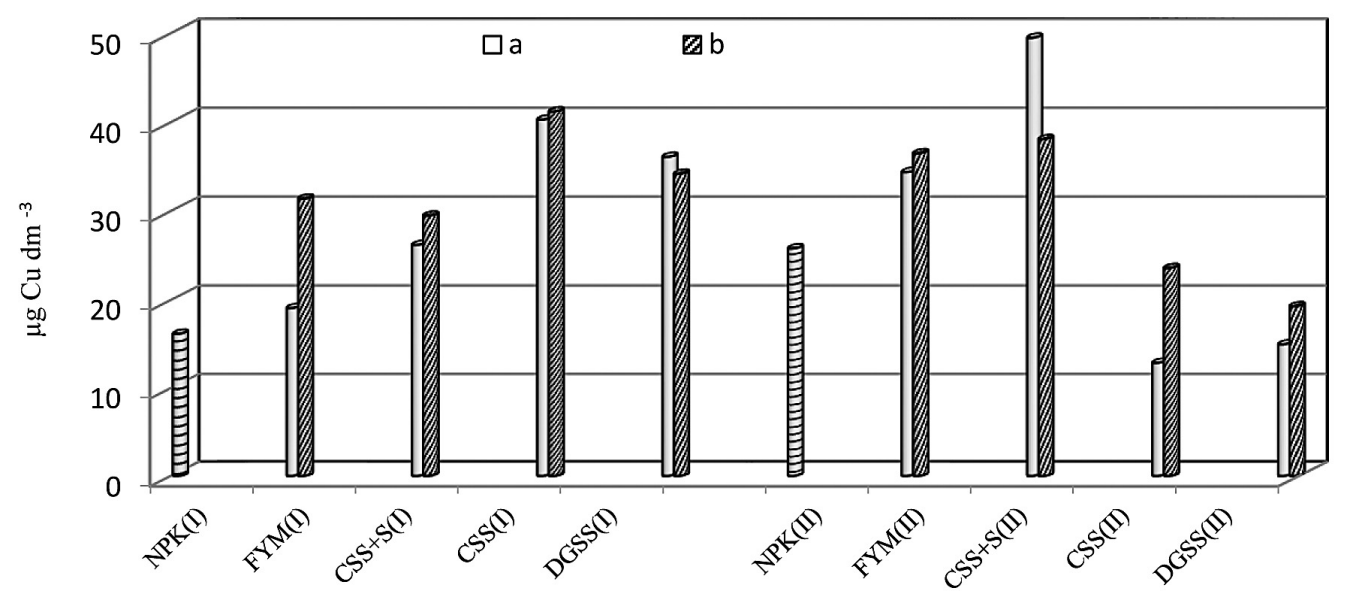

Figure 2. Content of copper in leachate $\left(\mathrm{css}^{+} \mathrm{s}-\right.$ compost from sewage sludge and straw; css - compost from sewage sludge; dgss - dried and granulated sewage sludge; (I) - first rotation; (II) - second rotation; $\mathrm{a}-$ once in a rotation $\mathrm{b}-$ twice in a rotation)

to water environment. Kopeć et al. [1991] demonstrated that the use of organic fertilization reduced the transfer of microelements deep into the soil profile.

The content of zinc in leachate from soils fertilized with NPK, FYM, composts and dried sewage sludge was significantly varied depending on the rotation (Figure 1). After the first rotation, the amount of zinc in leachate ranged from 10.0 to $26.1 \mu \mathrm{g} \cdot \mathrm{dm}^{-3}$, and after the second one was twice as high (from 25.0 to $45.4 \mu \mathrm{g} \cdot \mathrm{dm}^{-3}$ ). The highest loss of zinc by leaching in the first and second rotation (on average 24.7 and 45.4 $\mu \mathrm{g} \cdot \mathrm{dm}^{-3}$ ) was found in the soil leachate from the treatment fertilized by compost from sewage sludge (containing $1310 \mathrm{mg} \mathrm{Zn \cdot kg} \mathrm{d.m.).} \mathrm{Fertil-}$ ization of soil with compost from sewage sludge and straw or with dried and granulated sewage sludge modified the content of zinc in leachate differently depending on the frequency of application. In both rotations, the leaching of $\mathrm{Zn}$ from soil was higher following the application of composts, which were 3- to 7-fold richer in this element than FYM.

The hydrogeochemical background characteristic for the groudwaters in Poland varies from 0.01 to $0.5 \mathrm{mg} \mathrm{Cu} \cdot \mathrm{dm}^{-3}$ [Rozporządzenie... 2008]. Among the organic materials used for soil fertilization, sewage sludge composted without straw contained most copper ( $340 \mathrm{mg} \cdot \mathrm{kg}^{-1}$ s.m.). This explains why the leachate collected after the first rotation from this treatment also had the highest copper content (on average $40.7 \mu \mathrm{g} \cdot \mathrm{dm}^{-3}$ ) (Figure 2). Less copper was leached after the appliction of dried sewage sludge (on average $35.1 \mu \mathrm{g} \cdot \mathrm{dm}^{-3}$ ) and compost with straw (on av- erage $27.8 \mu \mathrm{g} \cdot \mathrm{dm}^{-3}$ ). The least copper was lost by leaching from soil with mineral fertilization alone $\left(16.2 \mu \mathrm{g} \mathrm{dm}^{-3}\right)$. In the second rotation, the content of copper in leachate from soil fertilized by sewage sludge composted without any additives was the lowest (above $17 \mu \mathrm{g} \cdot \mathrm{dm}^{-3}$ ), and the highest one was determined after the application of compost with straw (on average $43.8 \mu \mathrm{g} \cdot \mathrm{dm}^{-3}$ ).

\section{CONCLUSIONS}

1. Application of sewage sludge composted without straw one or twice during a rotation cycle to fertilize soil significantly increases the soil content of available forms of zinc and copper, but retains the same soil abundance class (medium for $\mathrm{Zn}$ and low for $\mathrm{Cu}$ )

2. The content of zinc and copper in soil leachate varies depending on the rotation and applied fertilization. Most copper in both rotations ( 24.7 and $45.4 \mu \mathrm{g} \cdot \mathrm{dm}^{-3}$ ) is leached from soil fertilized with composted sewage sludge. In the first rotation, most copper $\left(40.7 \mu \mathrm{g} \cdot \mathrm{dm}^{-3}\right)$ was also leached from the soil fertilized with this compost, but in the second rotation the highest loss of copper by leaching occurred from soil fertilized with sewage sludge composted with straw $\left(43.8 \mu \mathrm{g} \cdot \mathrm{dm}^{-3}\right)$.

\section{REFERENCES}

1. Bowszys T., Wierzbowska J., Bowszys J. 2009a. Content and removal of $\mathrm{Cu}$ and $\mathrm{Zn}$ with harvested crops grown on soil fertilized with composted municipal sewage sludge. J. Elem. 14(1), 23-32. 
2. Bowszys T., Wierzbowska J., Bowszys J., Bieniek A. 2009b. Modifications in the content of available zinc and copper in soil fertilized with bio-waste compost. J. Elementol., 14(1), 33-42

3. Gawdzik J., 2012. Mobilność metali ciężkich w osadach ściekowych na przykładzie wybranej oczyszczalni ścieków. Inżynieria i Ochrona Środowiska, 15, 1, 5-15.

4. Gondek K. 2009. Wpływ nawożenia na zawartość mobilnych form wybranych mikroelementów w glebie oraz ich wymycie w doświadczeniu wazonowym. Acta Agroph. 13(1), 89-101.

5. Gondek K. 2010. Zinc and cadmium accumulation in maize (Zea maysL.) and the concentration mobile forms of these metals in soil after application of farmyard FYM and sewage sludge. J. Elementol., 15(4), 639-652.

6. Greinert A., Drab M., Węclewski S. 2009. Ryzyko chemicznego zanieczyszczenia gleb nawożonych osadami ściekowymi. Zesz. Prob. Post. Nauk Rol. $537,135-144$.

7. Iżewska A. 2007. Wpływ nawożenia obornikiem, osadem ściekowym i kompostem i osadów ściekowych na właściwości gleby. Zesz. Probl. Post. Nauk Rol. 518, 85-92.

8. Kopeć S., Nowak K., Smoroń S. 1991. Straty składników nawozowych przez wymywanie w zależności od nawożenia i uprawianej rośliny. Roczn. Glebozn. XLII, 3/4, 109-114.

9. Milinovic J., Vidal M., Lacorte S., Rigol A. 2014. Leaching of heavy metals and alkylphenolic compounds from fresh and dried sewage sludge. Environ Sci Pollut Res, 21, 2009-2017.

10. Niedźwiecki E., Wojcieszczuk T., Meller E., Fedorowicz J. 2009. Oddziaływanie kompostów wytworzonych $\mathrm{w}$ zakładzie utylizacji odpadów w Gorzowie Wielkopolskim na skład chemiczny gleb. Zesz. Probl. Post. Nauk Rol. 537, 249-254.
11. Page K., Harbottle M.J., Cleall P.J., Hutchings T.R. 2014. Heavy metal leaching and environmental risk from the use of compost-like output as an energy crop growth substrate. Science of the Total Environment 487, 260-271.

12. Rocznik Statystyczny 2013. GUS, Ochrona środowiska, http://stat.gov.pl/.

13. Rozporządzenie Ministra Środowiska z dnia 23 lipca 2008 r. w sprawie kryteriów i sposobów oceny wód podziemnych. Dz.U z 2008 r. Nr 143, poz. 896.

14. Sądej W., Bowszys T., Wierzbowska J. 2007. Kształtowanie właściwości fizykochemicznych gleby płowej nawożonej osadami ściekowymi. Zesz. Probl. Post. Nauk Rol., 520, 363-369.

15. Sevel L., Ingerslev M., Nord-Larsen T., Jørgensen U., Holm P. E., Schelde K. 2014. Fertilization of SRC Willow, II: Leaching and Element Balances, Bioenerg. Res., 7, 338-352

16. Sienkiewicz S., Czarnecka M. 2012. Content of available $\mathrm{C}, \mathrm{Zn}$ and $\mathrm{Mn}$ in soil amended with $\mathrm{mu}-$ nicipal sewage sludge. J. Elem. 17(4), 649-657.

17. Sienkiewicz S., Wojnowska T., Krzebietke S., Wierzbowska J., Żarczyński P. 2009. Content of available forms of some micronutrients in soil after long-term differentiated fertilization. J. Elem. 14(4), 787-794.

18. Systematyka gleb Polski. 2011. Rocz. Glebozn. LXII (3), 1-193.

19. Wieczorek J., Frączek K. 2013. Assessment of possibility of agricultural use of municipal sewage sludge generated in selected small sewage treatment plants from Kraków district. J. Ecol. Eng. 14, 2, 36-42.

20. Witczak S., Adamczyk A. 1995. Katalog wybranych fizycznych i chemicznych wskaźników zanieczyszczenia wód podziemnych i metod ich oznaczania. T. 2, Biblioteka Monitoringu Środowiska PIOŚ, Warszawa. 